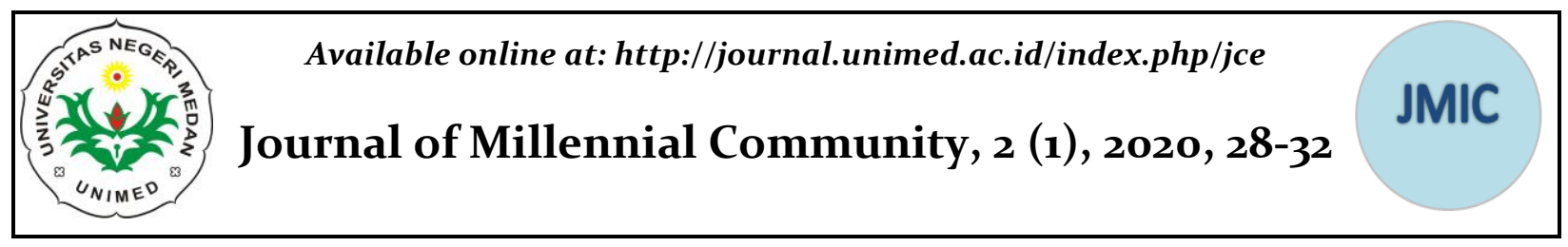

\title{
Puah Manus sebagai Sarana Pembelajaran Masyarakat Suku Timor, Nusa Tenggara Timur
}

\author{
Nirwaning Makleat \\ Program Studi Pendidikan Luar Sekolah, Universitas Nusa Cendana \\ Email: nirwaningmakleat@staf.undana.ac.id
}

\begin{abstract}
Abstrak
Penelitian ini bertujuan untuk mengungkapkan nilai-nilai pembelajaran yang terkandung dalam tradisi puah manus masyarakat suku Timor, Nusa Tenggara Timur. Penelitian ini menggunakan metode kualitatif etnografis dengan subjek penelitian terdiri dari tokoh adat dan masyarakat suku Timor, Nusa Tenggara Timur. Pengumpulan data dilakukan melalui pengamatan, wawancara mendalam dan dokumentasi. Teknik sampling yang digunakan adalah purposive sampling dan snowball sampling. Keabsahan data penelitian menggunakan teknik trianggulasi. Hasil penelitian menunjukkan bahwa puah manus sebagai tradisi turun temurun mengandung nilai-nilai pembelajaran informal dan non formal bagi masyarakat suku Timor, Nusa Tenggara Timur. Nilainilai pembelajaran tersebut antara lain 1) belajar menghargai orang lain melalui kebiasaan menyambut tamu dengan menyuguhkan puah manus; 2) belajar bertutur kata yang baik dan bersikap sopan santun saat berbicara dengan orang lain melalui kebiasaan menyuguhkan puah manus sebagai "alas mulut"; 3) belajar mempererat ikatan tali persaudaraan tanpa mengenal adanya perbedaan melalui kebiasaan mamah puah manus (mengunyah sirih pinang); 4) belajar memecahkan masalah melalui tradisi puah manus.
\end{abstract}

Kata kunci: puah manus, suku timor

\section{Puah Manus as a Learning Facility for Timorese, East Nusa Tenggara}

\begin{abstract}
This study aims to reveal the learning values contained in the puah manus tradition of the Timorese. This research uses ethnographic qualitative methods. The subjects of the study were traditional leaders and Timorese people. Data collection is done through observation, in-depth interviews, and documentation. Determination of the subject using purposive sampling and snowball sampling. The validity of research data uses triangulation techniques. The results showed that puah manus as a hereditary tradition contained the values of informal and nonformal learning for Timorese, East Nusa Tenggara, Indonesia. The learning values include: 1) learning to respect others through the habit of welcoming guests by offering puah manus; 2) learn to speak good words and talk politely while offering puah manus as a medium to soften words; 3 ) learn to strengthen the bond of kinship without recognizing differences through the habit of mamah puah manus which means chewing betel nut; 4) learn to solve problems through the traditions of puah manus.
\end{abstract}

Keywords: puah manus, timorese-Indonesia 


\section{PENDAHULUAN}

Budaya merupakan tingkatan paling tinggi dalam kehidupan sebab sistem nilai budaya berisikan berbagai konsep penting yang terkait dengan perkembangan kehidupan manusia, salah satunya yakni "pengertian diri" (self-concept). Perkembangan self concept terjadi saat seseorang berada dalam masa kanak-kanak. Pada masa ini anak mulai belajar menggambarkan dirinya akan menjadi apa atau ingin menjadi seperti siapa. Gambaran-gambaran tersebut merupakan akibat dari bertambah kompleksnya interaksi dengan orang lain, tidak hanya dalam tahap sosialisasi primer dalam keluarga namun juga sosialisasi luas dengan masyarakat (Suparlan, 1975). Melalui proses sosialisasi, seseorang dapat belajar tentang siapa dirinya dan bagaimana seharusnya ia bertindak dalam lingkungan sosial. Dengan kata lain, proses pembudayaan merupakan sebuah proses pembelajaran. Proses pembelajaran dalam konteks budaya sebagai sumber pedoman hidup ini jelas akan berbeda antara individu yang satu dengan individu yang lain, tergantung konteks budaya di mana seseorang itu bertumbuh.

Puah manus merupakan salah satu sumber pedoman belajar masyarakat suku Timor, Nusa Tenggara Timur. Puah manus yang berarti sirih pinang seakan tidak dapat dipisahkan dengan kehidupan masyarakat suku Timor (Suparlan, 1975). Kebiasaan memamah (mengunyah) sirih pinang membuat masyarakat suku Timor selalu menjadikan puah manus sebagai suguhan utama bagi siapapun yang bertamu ke rumah masyarakat suku Timor. Tidak heran di setiap rumah akan ditemukan tempat sirih dan pinang.

Bagaimana tradisi puah manus dapat menjadi sumber pedoman belajar masyarakat suku Timor? Nilai-nilai pembeajaran apa saja yang terkadung dalam tradisi puah manus masyarakat suku Timor? Pertanyaan-pertanyaan mendasar inilah yang menjadi sumber acuan kajian penulisan ini.

\section{METODE}

Penelitian ini merupakan jenis penelitian kualitatif dengan pendekatan etnografis yakni pendekatan yang berupaya memperhatikan makna tindakan dari kejadian yang menimpa subyek yang diteliti. Pendekatan penelitian ini dimaksudkan untuk menguraikan lebih mendalam terkait nilai-nilai pembelajaran yang terkadung dalam tradisi puah manus masyarakat suku Timor, Nusa Tenggara Timur.

Subjek yang diteliti dalam kajian ini antara lain, tokoh adat (tua adat) dan masyarakat suku Timor. Teknik pengumpulan data dilakukan melalui observasi, wawancara mendalam (in depth interview) dan dokumentasi. Keabsahan data penelitian ini didasarkan pada 4 standar keabsahan hasil penelitian kualitatif yakni validasi internal (credibility), validasi eksternal (transferability), reliabilitas (depenapibility) dan obyektifitas (confirmability). Sejalan dengan prinsip berkesinambungan dalam metode penelitian kualitatif maka teknik analisis data penelitian ini dilakukan melalui proses reduksi data, penyajian data dan verifikasi atau penarikan kesimpulan.

\section{HASIL DAN PEMBAHASAN}

Hasil kajian penelitian ini menunjukkan bahwa tradisi puah manus masyarakat suku Timor, Nusa Tenggara Timur mengandung niai-nilai pembelajaran sebagai berikut:

\section{Belajar dari Kebiasaan Menyambut Tamu dengan Puah Manus}

Puah manus telah menjadi bagian yang tidak terpisahan dari kehidupan sosial masyarakat suku Timor. Tradisi kepemilikan tempat sirih pinang di setiap rumah, baik yang bermukim di wilayah pedesaan maupun di perkotaan seolah menandakan puah manus tidak dapat dihapuaskan dari kehidupan masyarakat Timor. Kebiasaan ini tidak dapat dipisahkan dengan pemahaman masyarakat mengenai puah manus yang dimaknai sebagai simbol penghargaan 
terhadap kehadiran Tuhan dan para moyang masyarakat suku Timor. Wujud kehadiran inilah yang membuat masyarakar tetap menghargai dan melestraikan puah manus sebagai salah satu budaya yang terus diwariskan dari generasi ke generasi.

Pemahaman inilah yang pada gilirannya membawa masyarakat sampai pada pemahaman bahwa puah manus merupakan simbol penghargaan terhadap orang di sekitar. Puah manus yang tersedia di setiap rumah tidak hanya dimaknai sebagai wujud penghargaan terhadap Tuhan dan para moyang tetapi juga sekaligus bermakna bahwa masyarakat suku Timor selalu menyambut kedatangan siapapun dengan penuh penghargaan. Bentuk penghargaan itu tdak hanya disimbolkan secara asbtrak tetapi juga diiringi dengan sikap yang nyata yakni masyarakat terbiasa berlutut saat menyuguhkan puah manus kepada orang lain.

Sikap berlutut sambil menyuguhkan puah manus ini tidak hanya menjadi bentuk penghargaan terhadap orang lain tetapi juga menjadi simbol keberadaan diri masyarakat suku Timor. Hal inilah yang menyebabkan masyarakat suku Timor tidak akan pernah menolak suguhan puah manus sebab dengan mengambil suguhan puah manus berarti orang tersebut dihargai sekaligus menghargai keberadaan si penyuguh puah manus.

Dengan demikian dapat dilihat bahwa puah manus merupakan salah satu tradisi masyarakat suku Timor yang mampu menjadi sarana pembelajaran bagi masyarakat untuk saling menghargai.

\section{Belajar dari Kebiasaan Menyuguhkan Puah Manus sebagai “Alas Mulut”}

Dalam tradisi masyarakat Timor, saat seseorang ingin mengungkapkan harapannya kepada orang lain, terlebih dahulu perlu menyuguhkan puah manus. Kebiasaan seseorang menyuguhkan puah manus sebelum bertutur kata untuk menyampaikan harapan dan permohonan ini biasanya dikenal dengan istilah "alas mulut". Suguhan puah manus diyakini dapat menjadi pengantar/jembatan yang dapat lebih mengakrabkan seseorang dengan orang lain dalam menyatakan suatu harapan/permohonan.

Dalam kebiasaan masyarakat, saat seorang tamu datang dan menyuguhkan Page|30 puah manus kepada sang pemilik rumah maka berarti tamu tersebut memiliki suatu maksud yang hendak disampaikan. Dahulu biasanya seseorang yang datang bertamu dan menyuguhkan puah manus memiliki maksud hendak meminta belukar untuk pakan ternak ataupun meminta tanah untuk diolah. Hingga saat ini puah manus masih sering digunakan masyarakat untuk menyampaikan undangan (secara lisan) untuk hadir dalam suatu acara. Tradisi yang masih terus dilestarikan ini menunjukkan bahwa puah manus memiliki titik tekan nilai pembelajaran yang berharga bagi masyarakat suku Timor, khususnya dalam bertutur kata yang baik dan sopan saat hendak menyampaikan maksud atau permohonan kepada orang lain.

\section{Belajar dari Kebiasaan Mamah Puah Manus}

Kehadiran puah manus dalam kehidupan masyarakat suku Timor sangat terkait dengan kebiasaan mamah (mengunyah) sirih pinang. Ibarat seorang perokok, hampir sebagian masyarakat, baik laki-laki maupun perempuan selalu menjadikan puah manus sebagai sarapan utama setiap pagi sebelum menyantap makanan dan di sela-sela waktu yang ada. Kebiasaan inilah yang membuat puah manus tidak pernah terlepas dari kehidupan masyarakat. Puah manus dimaknai sebagai sarana yang dapat mempereart tali persaudaraan antara sesama.

Makna ini muncul dari penghayatan masyarakat dimana ketika sirih, pinang dan kapur dimakan secara bersama-sama akan menghasilkan satu warna yaitu warna merah. Warna merah inilah yang selanjutnya ditarik pada pemahaman bahwa semua manusia berasal dari satu 
darah sehingga semuanya adalah saudara tanpa memandang perbedaan apapun. Penghayatan nilai inilah yang nampak dalam praktek hidup masyarakat suku Timor yang memiliki kebiasaan menyuguhkan puah manus kepada siapapun yang datang bertandang ke pulau Timor. Dalam kebiasaan ini, nampak jelas bahwa tradisi puah manus mengajarkan masyarakat suku Timor untuk selalu menjalin dan mempererat ikatan tali persaudaraan dengan siapapun tanpa mengenal adanya perbedaan agama, suku, ras maupun status sosial.

\section{Belajar dari Kebiasaan Menyelesaikan Masalah melalui "Pendekatan Puah Manus"}

Puah manus sebagai simbol persaudaraan, pada gilirannya turut menjadikannya sebagai media perdamaian saat muncul masalah atau pertikaian dalam relasi sosial masyarakat suku Timor. Dalam masalah keseharian seperti batas tanah atau hewan yang memakan tanaman orang lain, pihak yang bersalah biasanya akan langsung datang menyuguhkan puah manus kepada pihak yang dirugikan. Khusus dalam beberapa masalah yang terbilang rumit, seperti kekerasan, pemerkosaan bahkan pembunuhan, pihak yang bersalah akan meminta bantuan tokoh adat guna menyuguhkan puah manus sekaligus menyampaikan niat damai kepada pihak korban dengan menggunakan bahasa (tutur) adat setempat. Menariknya dalam praktek penyelesaian masalah melalui puah manus, pihak-pihak yang bertikai selalu dapat duduk bersama dengan hati yang dingin guna menyelesaikan masalah yang dihadapi. Umumnya masyarakat suku Timor meyakini bahwa tindakan menyelesaikan masalah melalui jalur hukum merupakan tindakan yang memalukan "nama baik" marga dan justru akan menimbulkan dendam yang berkepanjangan. Sebaliknya melalui puah manus, masyarakat meyakini bahwa masalah akan dapat terselesaikan secara kekeluargaan tanpa dendam antara pihak-pihak yang bertikai. Dalam hal ini dapat dilihat bahwa tradisi puah manus mampu mengajarkan masyarakat suku Timor belajar untuk mencari solusi bersama atas permasalahan yang dihadapi. Dengan kata lain, tradisi puah manus mampu menjadi sarana pembelajaran bagi masyarakat dalam memecahkan masalah (problem solving).

\section{SIMPULAN}

Puah manus merupakan warisan budaya masyarakat suku Timor yang kaya akan nilai-nilai pembelajaran. Dapat dilihat puah manus mampu mengajarkan masyarakat nilai-nilai etika dalam menjalin relasi dengan orang lain, nilai moral dan nilai hukum. Proses pewarisan dan internalisasi nilai-nilai pembelajaran tersebut pada dasarnya terjadi melalui pelibatan masyarakat secara langsung dalam berbagai situasi pembelajaran, baik secara informal dalam keluarga maupun non formal dalam masyarakat. Proses internalisasi secara turun temurun inilah yang selanjutnya mempengaruhi self concept masyarakat suku Timor dan membuat tradisi ini masih terus dipraktekkan dalam kehidupan masyarakat hingga saat ini. Dengan demikian dapat dilihat bahwa proses pembelajaran sejatinya tidak hanya terjadi secara formal di sekolah tetapi juga terjadi dalam relasi sosial masyarakat.

Dalam hal ini nampak adanya keterkaitan yang erat antara proses belajar informal, formal dan non formal. Keterikatan inilah yang pada akhirnya perlu terus dilestarikan guna meningkatkan minat dan semangat belajar masyarakat sebab pembelajaran sejatinya melibatkan kebiasaan atau tradisi yang telah mengakar dalam kehidupan masyarakat itu sendiri.

\section{DAFTAR PUSTAKA}

Afrizal. (2016). Metode Penelitian Kualitatif: Sebuah Upaya Mendukung Penggunaan Penelitian Kualitatif Dalam Berbagai Disiplin Ilmu. Jakarta: PT. RajaGrafindo Persada. 
Abdullah Irwan. (2010). Konstruksi $\mathcal{E}$ Reproduksi Kebudayaan. Yogyakarta: Pustaka Pelajar.

Creswell, Jhon W. (2014). Penelitian Kualitatif dan Desai Riset: Memilih di Antara Lima Pendekatan. Yogyakarta: Pustaka Pelajar

Fenwick, T.J. (2003). Learning Through Experience: Troubling Orthodoxies and Intersecting Questions. Florida: Krieger Publishing Company Malabar.

Illeris, K. (2004). The Three Dimensions of Learning. Florida: Krieger Publishing Sompany.

Mezirow, J. \& Associetes. (200o). Learning as Transformation. San Fransisco: Jossey-Bass.

Nainggolan, E. E., Nainggolan, E., Susanti, S., Silitonga, M. D., \& Irwan, M. (2019, December). Community Participation within the Implementation of the Senior High School Equality Education Program in PKBM Cahaya. In 5th International Conference on Education and Technology (ICET 2019). Atlantis Press.

Parsudi Suparlan. (1975). Kebudayaan Timor. Dalam Koentjaraningrat (Eds). Manusia dan Kebudayaan di Indonesia. Jakarta Pusat: Djambatan

Tallo, P.A. (1990). Okomama Simbol Pendekatan Masyarakat di Timor, tidak diterbitkan, Bupati Kepala Daerah Tingkat II Timor Tengah Selatan, Kota Soe

\section{PROFIL SINGKAT}

Nirwaning Makleat, lahir di Soe, Nusa Tenggara Timur, o3 November 1986. Menyelesaikan pendidikan Sarjana Sains Theologia di Universitas Kristen Duta Wacana Yogyakarta pada tahun 2009 dan Page|32 Magister Pendidikan Luar Sekolah di Universitas Negeri Yogyakarta tahun 2012. Saat ini aktif sebagai Dosen di Program Studi Pendidikan Luar Sekolah, Fakultas Keguruan dan Ilmu Pendidikan, Universitas Nusa Cendana Kupang. 